\title{
XYY Sex Chromosomes in a Jamaican with Orthopaedic Abnormalities
}

\section{MARIGOLD J. THORBURN, WINSTON CHUTKAN, ROLF RICHARDS, and RUTH BELL}

\author{
From the University of the West Indies, Mona, Kingston 7, famaica
}

Patients with a sex chromosome complement of XYY in whom the physical findings vary from apparent normal maleness, to genital anomalies, mental defect, and criminal tendencies have been described by several authors. The one common feature in the adult cases has been tallness. We here report an adult male with an XYY complement who, in addition to mental defect, hypogonadism, and increased height showed interesting orthopaedic abnormalities.

\section{Case Report}

The patient was a 28-year-old Jamaican man of mainly African extraction, who presented to the Orthopaedic Clinic of the University College Hospital of the West Indies with deformities of both knees, which had been present for approximately 8 years. He also complained of retrosternal pain on exertion. On examination he was a tall slim mentally retarded man with right genu varum and left genu valgum (Fig. 1). There were scars of old varicose ulcers on both legs. He was $227 \mathrm{~cm}$.

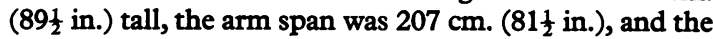
sole-pubis measurement was $121 \mathrm{~cm}$. ( $\left(47 \frac{1}{2} \mathrm{in}\right.$.). The only other abnormality was that both testes were small. An initial clinical diagnosis of pituitary gigantism was made, with hypogonadism and mental retardation.

Family and Social History. This was obtained from an older sister as the patient was unable to give adequate details. The patient was the youngest of a family of 12 children. Both parents are alive and well at the ages of 77 and 71 . The maternal age at birth was 43 and the paternal age 49 . The oldest sib is 50 . Two sisters died at the age of 26 years and 6 months, after 4 abdominal operations, and of 'influenza', respectively. All the living sibs except one have had normal children and all are tall. The sister supplying the history was 180 $\mathrm{cm}$. (71 in.) in height and the father was said to be nearly as tall as the patient. Unfortunately no other members of the family could be interviewed as they lived in scattered parts of the island. However, all are said to be of normal

Received October 3, 1967. intelligence and had been to school, whereas the patient had not been sent to school because he was too dull. He lived with his parents in the country and did a little cultivating.

Investigations. The visual fields were normal.

Examination of the blood showed $\mathrm{Hb} 10.7 \mathrm{~g} . / 100 \mathrm{ml}$., white cell count $3800 / \mathrm{cu} . \mathrm{mm}$. with $50 \%$ neutrophils, $34 \%$ lymphocytes, $10 \%$ eosinophils, and $6 \%$ monocytes.

Serum chemistry was normal. The serum calcium was $10.1 \mathrm{mg} . / 100 \mathrm{ml}$., phosphorus $3.4 \mathrm{mg} . / 100 \mathrm{ml}$., cholesterol $121 \mathrm{mg} . / 100 \mathrm{ml}$., urea $24 \mathrm{mg} . / 100 \mathrm{ml}$., total bilirubin $0.2 \mathrm{mg} . / 100 \mathrm{ml}$., alkaline phosphatase 13 King Armstrong units, total proteins $7.3 \mathrm{mg} . / 100 \mathrm{ml}$., albumin 4.8 , globulin $2.5 \mathrm{~g} . / 100 \mathrm{ml}$. Other tests of liver function were normal. Two glucose tolerance tests and radioactive iodine uptake were normal (19\% after 6 hours and $35 \%$ after 24 hours). $X$-ray examination of the skull was normal; the knees showed failure of closure of the epiphyses. The bone age was estimated as being between 15 and 18 years. There were no other skeletal abnormalities.

The urinary 17-ketosteroids were estimated at $0.9 \mathrm{mg}$. and the ketogenic steroids $4 \mathrm{mg}$. in 24 hours $(550 \mathrm{ml}$. urine). An electrocardiogram was normal. Testicular biopsy was refused.

Cytogenetic Examination. Buccal smears were sex chromatin negative. Peripheral blood was cultured by a slight modification of the microtechnique of Arakaki and Sparkes (1963) on 2 occasions, the second occasion being an attempt to demonstrate labelling of the $Y$ chromosomes by autoradiography. At least 30 cells were counted and analysed visually. All showed 47 chromosomes with 6 small acrocentrics. The extra chromosome was easily distinguishable in most cells as $Y$ (Fig. 2 ), by the morphological characteristics of fuzziness, short arms without satellites, approximation of long arms, and lack of association. Karyotyping confirmed this initial observation. In the second culture, tritiated thymidine was added 5 hours before termination of the culture, i.e. after $\mathbf{6 7}$ hours. There was a low proportion of labelled cells (32\%), and in 5 of these either one or 


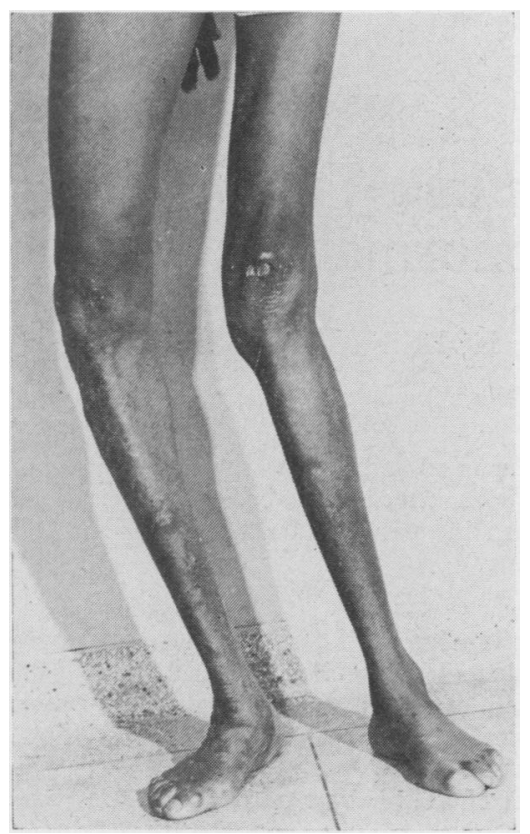

FIG. 1. Legs of patient showing 'sway' deformity.

both $\mathrm{Y}$ chromosomes were labelled in the absence of labelling of the $\mathrm{G}$ autosomes.

The patient was subsequently treated by bilateral osteotomies and androgen therapy in an attempt to prevent further growth.

\section{Discussion}

We consider that the extra chromosome is undoubtedly a Y, trisomy 21 being excluded on clinical grounds. The pattern of labelling appears to vary; in some cells both the $\mathrm{Y}$ chromosomes were labelled, in others only one. Balodimos et al. (1966) and Kikuchi and Sandberg (1965) found that the majority of cells showed synchronous labelling of the 2 Ys, whereas Kosenow and Pfeiffer (1966) reported discordant labelling. Both, however, found that they labelled more heavily and later than the $G$ autosomes. Our results seem to indicate that both occur, and the different patterns may depend on the technique used or the time of addition of the thymidine to the leucocyte culture.

Several aspects of this patient's clinical picture are of considerable interest. In Table I we have compared the clinical findings and family history of our patient with those of other reported adult patients with the chromosome constitution of XYY. We have purposely omitted those cases with more than one $\mathrm{X}$ chromosome, as the features of these are influenced by the selection of chromatin positive males in mental institutions and the clinical picture is modified by the presence of the extra $\mathrm{X}$ chromosomes. We have also excluded children under the age of 15 years as they are more likely to be selectef because of genital or other anomalies. We haves been able to collect 16 cases, 9 of which were part of a series described by Price et al. (1966) of inmates

TABLE I

COMPARISON OF FEATURES OF ADULTS WITH XYY

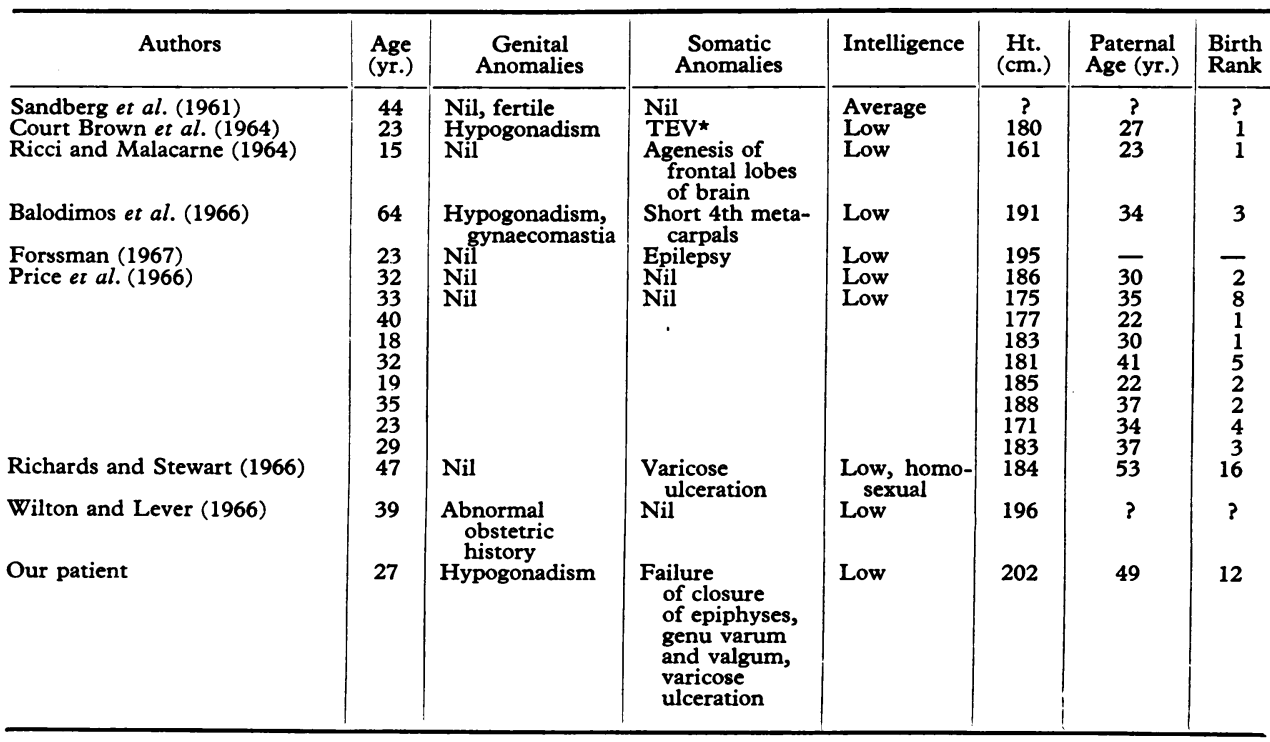

$\star$ Talipes equinovarus. 


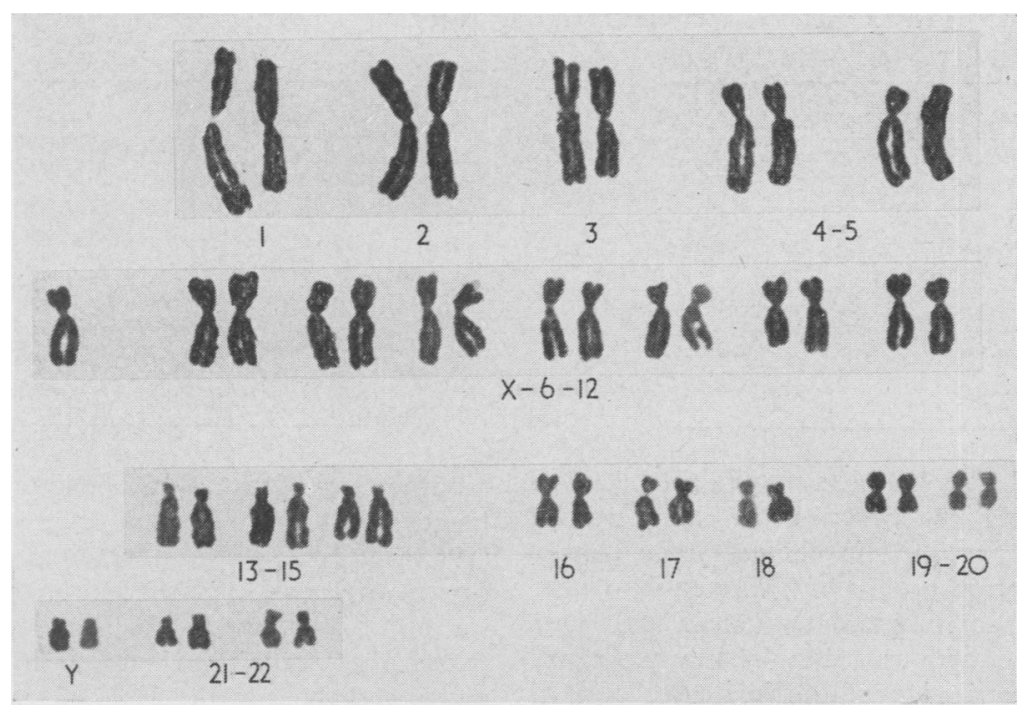

FIG. 2. (a) Karyotype of patient showing $2 \mathrm{Y}$ chromosomes.

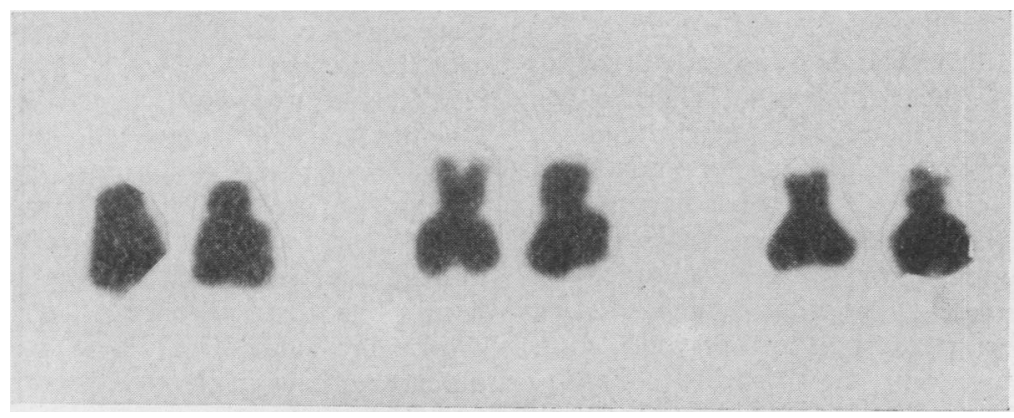

(b) Enlargement, showing fuzziness, and approximation of short arms.

at a special institution for the detention of mentally subnormal or unstable patients with tendencies to violence. The series of 18 subjects described by Casey et al. (1966) has been omitted from Table I, as no clinical details other than height and the mental state of the patients are given. None of the adult patients or any of the children previously reported (Fraccaro et al., 1962; Hayward and Bower, 1960; Sandberg et al., 1963; Milcu et al., 1964; Hustinx and van Olphen, 1963; Vignetti, Capotorti, and Ferrante, 1964; Verresen and van den Berghe, 1965) have had deformities of the type seen in our patient. Presumably these are due to failure of closure of the epiphyses. Dunn et al. (1961) described a child who had delayed osseous development, and Hustinx and van Olphen's patient (1963) had Marfan's syndrome, but in none of the adult cases was skeletal maturation delayed. Delay in epiphysial closure may be associated with hypogonadism where it is presumably due to low levels of androgens. Pituitary gigantism was excluded in our patient, so we must conclude that his excessive height was due to a combination of some or all of the following: a familial tendency to tallness, delay in closure of the epiphyses, hypogonadism, and the presence of $2 \mathrm{Y}$ chromosomes. Whether these are related to each other as cause and effect is debatable. Only 3 of the 16 adults in Table I had hypogonadism, so it is certainly not yet a proven part of the so-called YY syndrome. If there was really a true relation between the syndrome and hypogonadism, one would expect 2 Ys to have been detected in investigations of patients with the latter condition.

In Table I all the cases except one have been of low intelligence, though 6 of the cases of Casey et al. (1966) were normal. This again may be significant or may just reflect the mode of selection of patients. Similarly, the tendency to criminal, irresponsible, and violent behaviour (Casey et al., 1966; Price and 
TABLE II

MATERNAL AGE

\begin{tabular}{c|c|c}
\hline \multicolumn{1}{c|}{ Age-group } & Propositi & Control \\
\hline$<19$ years & 2 & 52 \\
$20-24$ & 5 & 127 \\
$25-29$ & 2 & 101 \\
$30-34$ & 5 & 76 \\
$35-39$ & 2 & 46 \\
40 and over & 2 & 9 \\
\hline Total & 18 & 411 \\
\hline Mean age & 28.7 years & 26.6 years \\
\hline Difference & \multicolumn{2}{|c}{$(p>0 \cdot 1)$} \\
\hline
\end{tabular}

Whatmore, 1967) may be due partly to the selection of cases from criminal mental institutions; on the other hand, Casey et al. (1966) showed a much lower incidence in 'control' groups of $6 \mathrm{ft}$. men who were mentally ill and normal, without antisocial acts. Our patient was described as being 'rather peaceful'. More figures are needed of the incidence of $2 \mathrm{Y}$ chromosomes in a normal male population, though one male with XYY was seen in a 'control' group in Edinburgh.

Tallness seems to be the one undisputed feature of the syndrome. Our patient is the tallest of the patients reported, and the excess of height seems to be due to the combination of the factors mentioned above in addition to the 2 Ys. It has been postulated (Ferguson-Smith, 1965), from reviewing the chromosome complements of large numbers of patients with variants of gonadal dysgenesis, that there is a segment on the short arm of the X chromosome, which pairs with the $\mathrm{Y}$ : this is thought to carry genes for normal height. This area is lost in XO patients, and trisomic in YY patients.

Vascular abnormalities and varicose ulceration have been noted by Richards and Stewart (1966) in an XYY male, and by Carr, Barr, and Plunkett (1961), Barr et al. (1964), and by Davies (1966) in XXYY males. The latter found that his patient and another with $\mathrm{XXXY} / \mathrm{XXXXY}$ mosaicism had scleroderma. How varicose veins could be related to the YY syndrome provides interesting speculation. Possibly the additional leg length increases the tendency of the lower third of the leg to poor blood supply and predisposition to varicose ulceration. At the time of our patient's operation the cytogenetic diagnosis had not been made, so the opportunity to take a skin biopsy was missed.

The origin of the double $\mathrm{Y}$ condition is of interest. Obviously maternal considerations are irrelevant. A non-disjunctional error could occur either at spermatogenesis or during zygotic divisions. If the latter was the case, XYY/XO mosaicism would result, in which case one would expect a considerable
TABLE III

PATERNAL AGE

\begin{tabular}{|c|c|c|}
\hline Age-group & Propositi & Control \\
\hline $\begin{array}{l}<19 \text { years } \\
20-24 \\
25-29 \\
30-34 \\
35-39 \\
40 \text { and over }\end{array}$ & $\begin{array}{l}0 \\
3 \\
2 \\
5 \\
3 \\
5\end{array}$ & $\begin{array}{r}8 \\
105 \\
118 \\
91 \\
56 \\
33\end{array}$ \\
\hline Total & 18 & 411 \\
\hline Mean age & 32.8 years & 29.4 years \\
\hline Difference & \multicolumn{2}{|c|}{$(p=0.02)$} \\
\hline
\end{tabular}

modification of the clinical picture, especially the height, as in the case described by Cooper et al. (1962), more resembling mixed gonadal dysgenesis. Spermatogenesis is, therefore, the most likely source of the error. We therefore examined the paternal age of all the patients in Table I, where given, and those in the cases of Dunn et al. (1961), Vignetti et al. (1964), Verresen and van den Berghe (1965), and Kosenow and Pfeiffer (1966), to see if there was any suggestion of a significant increase over the normal.

We investigated both maternal and paternal ages. Due to the lack of homogeneity of the study group, no satisfactory control group could be obtainedo Instead we used the parental ages in the controf group cited by Woolf (1963) in his study on cleff lip and palate. Maternal ages were investigated first. The distributions of the two groups are shown in Table II. There was no significant difference between the two distributions $\left(\chi^{2}=5 \cdot 87\right)$ which allowed a direct comparison to be made between the mean ages. The mean maternal age of the propositi was $28 \cdot 7$ years and that of the control 26.6 years. Using Student's $t$ test, there was no significant difference between these ages $(p=0 \cdot 1)$. The paternal ages were treated in the same way and the distributions are shown in Table III. Again there was no difference between the distributions $\left(\chi^{2}=10 \cdot 62\right)$, and the mean ages were tested directly. The mean paternal age of the propositi was $32 \cdot 8$ years and that of the control group 29.4 years. Here there was a significant difference between the two groups $(p=0.02)$, showing that the paternal age of the propositi was older on average. Allowing for the small study group and the unsatisfactory control group, paternal age does seem to play a part in the appearance of XYY abnormalities.

\section{Summary}

A male Jamaican patient is described with bilateral deformities of the knees, mental retardation, and 
hypogonadism. He was found to have retarded bone age, varicose ulceration, a height of $227 \mathrm{~cm}$. (89 $\frac{1}{2}$ in.), and a XYY sex chromosome constitution. The relation of these features to the presence of $2 \mathrm{Y}$ chromosomes is discussed, and a paternal age effect is suggested in the origin of the XYY condition.

The cytogenetic work was supported by a grant from the Wellcome Trust. We thank Professor J. S. R. Golding for permission to publish the case, Dr. Eric Bateson for the radiological assessment, Mr. Colin Benjamin for his assistance with the autoradiography, and the staff of the department of Chemical Pathology for the laboratory work. Pure heparin, B.P., was provided by Boots Pure Drug Co., Nottingham.

\section{REFERENCES}

Arakaki, D. T., and Sparkes, R. S. (1963). Microtechnique for culturing leukocytes from whole blood. Cytogenetics, 2, 57.

Balodimos, M. C., Lisco, H., Irwin, I., Merrill, W., and Dingman, J. F. (1966). XYY karyotype in a case of familial hypogonadism. 7. clin. Enidocr., 26, 443.

Barr, M. L., Carr, D. H., Soltan, H. C., Wiens, R. G., and Plunkett, E. R. (1964). The XXYY variant of Klinefelter's syndrome. Canad. med. Ass. F., 90, 575.

Carr, D. H., Barr, M. L., and Plunkett, E. R. (1961). A probable $\mathrm{XXYY}$ sex determining mechanism in a mentally defective male with Klinefelter's syndrome. ibid., 84, 873.

Casey, M. D., Blank, C. E., Street, D. R. K., Segall, L. J., McDougall, J. H., McGrath, P. J., and Skinner, J. L. (1966). YY Chromosomes and antisocial behaviour. Lancet, 2, 859.

Cooper, H. L., Kupperman, H. S., Rendon, O. R., and Hirschhorn, K. (1962). Sex-chromosome mosaicism of type XYY/XO. New Engl. F. Med., 266, 699.

Court Brown, W. M., Harnden, D. G., Jacobs, P. A., Maclean, N., and Mantle, D. J. (1964). Abnormalities of the sex chromosome complement in man. Case No. 82/62. Spec. Rep. Ser. med. Res. Coun. (Lond.), No. 305, p. 107.

Davies, T. S. (1966). The YY syndrome. Lancet, 1, 1103.

Dunn, H. G., Ford, D. K., Auersperg, N., and Miller, J. R. (1961).
Benign congenital hypotonia with chromosomal anomaly. Pediatrics, 28, 578.

Ferguson-Smith, M. A. (1965). Karyotype-phenotype correlations in gonadal dysgenesis and their bearing on the pathogenesis of malformations. F. med. Genet., 2, 142.

Forssman, H. (1967). Epilepsy in an XYY man. Lancet, 1, 1389.

Fraccaro, M., Davies, P., Bott, M. G., and Schutt, W. (1962). Mental deficiency and undescended testis in two males with XYY sex chromosomes. Folia hered. path. (Milano), 11, 211.

Hayward, M. D., and Bower, B. D. (1960). Chromosomal trisomy associated with the Sturge-Weber syndrome. Lancet, 2, 844.

Hustinx, T. W. J., and van Olphen, A. H. F. (1963). An XYY chromosome pattern in a boy with Marfan's syndrome. Genetica, 34, 262.

Kikuchi, Y., and Sandberg, A. A. (1965). Chronology and pattern of human chromosome replication. II. Autoradiographic behaviour of various $\mathrm{Y}$ and $\mathrm{X}$ chromosomes. f. nat. Cancer Inst., 34, 795.

Kosenow, W., and Pfeiffer, R. A. (1966). YY syndrome with multiple malformations. Lancet, 1, 1375.

Milcu, St. M., Negoescu, I., Maximilian, C., Garoiu, M., Augustin, M., and Iliescu, I. (1964). Baiat cu hipospadias si cariotip XYY. Stud. Cercet. Endocr., 15, 347.

Price, W. H., Strong, J. A., Whatmore, P. B., and McClemont, W. F. (1966). Criminal patients with XYY sex-chromosome complement. Lancet, 1, 565.

- and Whatmore, P. B. (1967). Behaviour disorders and pattern of crime among XYY males identified at a maximum security hospital. Brit. med. F., 1, 533.

Ricci, N., and Malacarne, P. (1964). An XYY human male. Lancet, 1, 721

Richards, B. W., and Stewart, A. (1966). The YY syndrome. ibid., $1,984$.

Sandberg, A. A., Ishihara, T., Crosswhite, L. H., and Koepf, G. F. (1963). XYY genotype. Report of a case in a male. New Engl. F. Med., 268, 585.

-, Koepf, G. F., Ishihara, T., and Hauschka, T. S. (1961). An $X Y Y$ human male. Lancet, $2,488$.

Verresen, H., and van den Berghe, H. (1965). 21-trisomy and XYY. ibid., 1, 609.

Vignetti, P., Capotorti, L., and Ferrante, E. (1964). XYY chromosomal constitution with genital abnormality. ibid., 2,588 .

Wilton, E., and Lever, A. (1966). The YY syndrome. ibid., 1, 1156.

Woolf, C. M. (1963). Paternal age effect for cleft lip and palate. Amer. F. hum. Genet., 15, 389. 
Biology and the Social Crisis. A Social Biology for Everyman. By J. K. Brierley. (Pp. xix +260 ; 48 figures +33 tables. 35s.) London: Heinemann. 1967.

Dr. Brierley's delightfully written Biology and the Social Crisis is a broad survey intended as a 'social biology for everyman'. The opening sections on human heredity and on race cover nearly half the text: they are lucid and constitute an excellent introduction to human heredity. The two subsequent sections concern the more debatable grounds of food supply and expanding populations. Two further sections deal with some special social problems, such as crime, old age, and human behaviour, and here the lines of demarcation between established teaching, developing knowledge, and personal views are not always clear. There is, however, nothing that is not balanced and helpful.

\section{Corrigendum}

XYY Sex Chromosomes in a Jamaican with Orthopaedic Abnormalities, by Thorburn, Chutkan, Richards, and Bell, September 1968, Vol. 5, p. 215, line 10 of Case Report and p. 219, line 3

$89 \frac{1}{2}$ in. should read $79 \frac{1}{2}$ in. 